\title{
Randomised trial reports continue to be islands of evidence, with few continents in sight
}

\author{
Michael Clarke ${ }^{1 *}$, Sally Hopewell ${ }^{2,3}$ \\ From 2nd Clinical Trials Methodology Conference: Methodology Matters \\ Edinburgh, UK. 18-19 November 2013
}

\section{Background}

Existing evidence should provide ethical, scientific and environmental justification for a new trial and users of randomized trials need to see their findings within the context of similar trials. Since 1997, Annals of Internal Medicine, BMJ, JAMA, Lancet, and New England Journal of Medicine have been assessed to see if results are placed in context and, more recently, to see if systematic reviews are used to justify the trial.

\section{Methods}

We assessed each May 2012 issue of these journals to identify reports of randomized trials. Introduction sections were categorised as first trial, updated systematic review used in the design, systematic review mentioned, other trials mentioned, and no other trials mentioned with no claim to be the first trial. Discussion sections were categorised as first trial, systematic review integrating the new trial, systematic review mentioned, and no apparent systematic attempt to place findings in full context.

\section{Results}

35 reports of randomized trials were included. Introduction sections: 5 were said to be the first trial, 1 used an updated systematic review in the design, 13 discussed previous systematic reviews, 10 mentioned other trials, and 6 didn't mention other trials or claim to be the first. Discussion sections: 2 were said to be the first trial, 2 contained a systematic review integrating the new trial, 11 mentioned a systematic review, and 20 made no apparent systematic attempt to place findings in full context. There was variability across the journals.

${ }^{1}$ All-Ireland Hub for Trials Methodology Research, Belfast, UK

Full list of author information is available at the end of the article

\section{Conclusions}

Many trials still don't use systematic reviews in their design and reporting.

\section{Authors' details}

'All-Ireland Hub for Trials Methodology Research, Belfast, UK. ${ }^{2}$ Centre for Statistics in Medicine, Oxford, UK. ${ }^{3}$ French Cochrane Centre, INSERM, Paris, France.

Published: 29 November 2013

doi:10.1186/1745-6215-14-S1-095

Cite this article as: Clarke and Hopewell: Randomised trial reports continue to be islands of evidence, with few continents in sight. Trials 2013 14(Suppl 1):095.

\section{Submit your next manuscript to BioMed Central and take full advantage of: \\ - Convenient online submission \\ - Thorough peer review \\ - No space constraints or color figure charges \\ - Immediate publication on acceptance \\ - Inclusion in PubMed, CAS, Scopus and Google Scholar \\ - Research which is freely available for redistribution

